\title{
NATIONAL WATER-QUALITY ASSESSMENT PROGRAM Lower Tennessee River Basin
}

\section{MAJOR WATER-QUALITY ISSUES IN THE LOWER TENNESSEE RIVER BASIN}

Assessing water quality in the lower Tennessee River Basin is important for the protection and efficient use of water and aquatic resources. The Lower Tennessee River Basin NAWQA study will increase scientific understanding of surface- and ground-water quality within the basin and the factors that influence water quality and aquatic resources, such as fish and mussels.

The Lower Tennessee River Busin study unit is known for the prolific distribution of Cumberlandian mollusks. The Muscle Shoals area, near Florence, Alabama, once contained the most diverse assemblage of mussels in the world. Many of these species have been eliminated and several existing species are now endangered or threatened.

The NAWQA study also will provide information needed by water-resource managers to implement effective water-quality management actions and evaluate long-term changes in water quality. Some of the major water-quality issues that currently face water-resource managers in the Lower Tennessee River Basin include:

- Nutrient enrichment and nutrient concentration trends in streams, reservoirs, and aquifers from agricultural inputs, septic systems, and runoff from lawns in urban areas.

\section{WHAT IS THE NATIONAL WATER-QUALITY ASSESSMENT PROGRAM?}

During the past 25 years, industry and government made large financial investments that have resulted in improved water quality across the Nation; however, many waterquality concerns remain. The U.S. Geological Survey began a full-scale National WaterQuality Assessment (NAWQA) Program in 1991 to provide consistent and scientifically sound information for managing the Nation's water resources. This program is unique compared to other national water-quality assessment studies in that it integrates the monitoring of the quality of surface and ground waters with the study of aquatic ecosystems. The goals of the NAWQA Program are (1) to describe current water-quality conditions for a large part of the Nation's freshwater streams and aquifers (water-bearing sediments and rocks), (2) to describe how water quality is changing over time, and (3) to improve our understanding of the primary natural and human factors affecting water quality.



The goals of the NAWQA program are being achieved through ongoing or planned investigations of 59 of the Nation's most important river and aquifer systems, which are referred to as study units. These study units were selected to represent the diverse geography, water resources, and land and water uses of the Nation. The Lower Tennessee River Basin is one such study unit, encompassing the drainage area between Chattanooga, Tennessee, and Paducah, Kentucky. The U.S. Geological Survey began the Lower Tennessee River Basin NAWQA study in 1996.

- Sedimentation and increased concentrations of sediment in streams and reservoirs from erosion related to urbanization and agriculture.

- Impacts upon native species, including endangered Cumberlandian mollusks, related to changes in water quality and degradation of instream and riparian habitats.
- Bacterial contamination of surface and ground waters.

- Pesticides and other toxic compounds in streams and aquifers from agricultural, industrial, and domestic activities. 


\section{Study UNIT DESCRIPTION}

The Lower Tennessee River Basin NAWQA study unit extends from Chattanooga, Tennessee, to near Paducah, Kentucky, at the confluence of the Tennessee and Ohio Rivers. The study unit area is about 19,500 square miles $\left(\mathrm{mi}^{2}\right)$ of which about 57 percent is in Tennessee, 35 percent in Alabama. 5 percent in Kentucky, 2 percent in Mississippi, and 1 percent in Georgia. Population in the study unit is about 2.7 million (1995). The most populated cities in the study unit are Huntsville, Alabama (160,000), Chattanooga, Tennessee $(152,000)$, and Decatur, Alabama $(52,000)$. In 1995, about 220 million gallons a day were withdrawn from surface- and ground-water sources in the study unit to provide public drinking water to about 1.5 million people. Surface water is the principal source, accounting for about 70 percent of the water withdrawn for drinking water.

The main stem of the Tennessee River is highly regulated with few free-flowing stream reaches. Six major reservoirs constructed primarily by the Tennessee Valley Authority from the 1920's through the 1940's for purposes of power generation, navigation, and flood control are located along the lower Tennessee River. Three additional reservoirs are located on major tributaries. Reservoirs along the Tennessee River are also used extensively for drinking water and recreational activities such as fishing, swimming, and boating. Water-resource managers and the public are extremely interested in maintaining the high quality of these reservoirs.

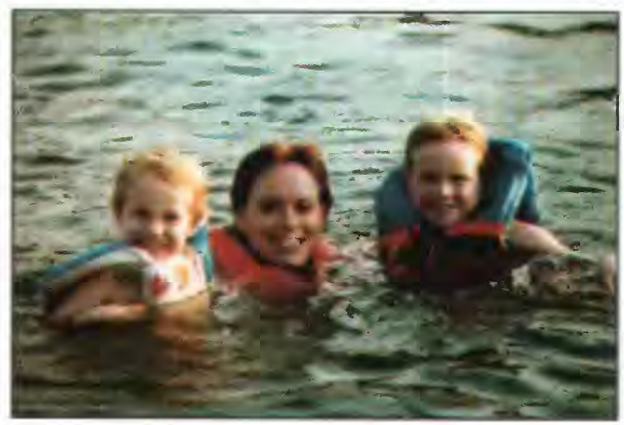

Nine reservoirs in the study unit are used extensively for water recreation.

The mean annual discharge at the outlet of the Tennessee River near Paducah, Kentucky, is 65,600 cubic feet per second $\left(\mathrm{ft}^{3} / \mathrm{s}\right)$. The mean annual discharge of the Tennessee River at the upstream boundary of the study unit at Chattanooga. Tennessee, is $35,900 \mathrm{ft}^{3} / \mathrm{s}$, thus the lower Tennessee River Basin contributes about $29,700 \mathrm{ft}^{3} / \mathrm{s}$ on an annual basis. The two largest basins in the study unit are the Duck River Basin, draining 2,700 $\mathrm{mi}^{2}$, and the Elk River Basin, draining $2.250 \mathrm{mi}^{2}$. The combined mean annual discharge of the Duck and



There are numerous industries along the main stem of the Tennessee River in northern Alabama. These industries manufacture and produce a variety of products, such as missiles and rockets. electronics, pulp and paper, synthetic fiber, terephthalic acid, alkalis, chlorine, steering gears, polyester film, refrigerators, aluminum, and nickel-plated foam. (Photograph courtesy of the Tennessee Valley Press. Decatur. Alabama)
Elk Rivers is about $7,700 \mathrm{ft}^{3} / \mathrm{s}$, or 26 percent of the mean annual discharge from the Lower Tennessee River Basin study unit.

The study unit lies within three physiographic provinces. The Coastal Plain Province is located along the western edge of the study unit and encompasses about 18 percent of the basin. To the east, the Interior Low Plateaus Province encompasses about 59 percent of the basin. The Cumberland Plateau Section of the Appalachian Plateaus Province is located along the eastern edge of the study unit and encompasses the remaining 23 percent of the basin. Land-surface elevations in the study unit range from about 300 feet above sea level in the Coastal Plain Province near Paducah, Kentucky, to more than 2,900 feet above sea level in the Cumberland Plateau, along the eastern edge of the Sequatchie River Basin. Annual precipitation varies from 47 inches in the Coastal Plain to 63 inches in the Cumberland Plateau. Average runoff ranges from 18 inches in the Coastal Plain to 30 inches in the Cumberland Plateau. The study unit has a temperate climate with an average annual temperature of about 58 degrees Fahrenheit.

Ground water is an important source of drinking water in rural areas and for numerous small public supply systems in the study unit. The Coastal Plain Province generally consists of a series of unconsolidated sands, gravels, silts, and clays. Shallow ground water in these sands and gravels is an important source of drinking water. In the Interior Low Plateaus Province, ground water moves through an overburden from 10 to more than 200 feet of regolith, a mixture of soil and weathered rock, and subsequently into an underlying carbonate aquifer. Carbonate aquifers are important sources of drinking water in many areas throughout the study unit. Thin regolith, caves, and sinkholes in this province increase the susceptibility of ground water to contamination from surface water. Most of the Cumberland Plateau is underlain by sandstones in which ground water occurs primarily in interconnected fractures.

The main land use in the study unit is forested land, which covers about 55 percent of the study unit (1992 land cover data from the Tennessee Valley Authority). Additional land uses include row crops and pasture land (41 percent), urban ( 1 percent), and other land uses ( 3 percent), such as wetlands, water, and barren land. Row crops occur predominantly along the main stem and small tributaries of the Tennessee River in northern Alabama and along the western edge of the study unit. Cotton, corn, and soybeans are the primary row crops. Confined animal operations are concentrated primarily in northern Alabama.

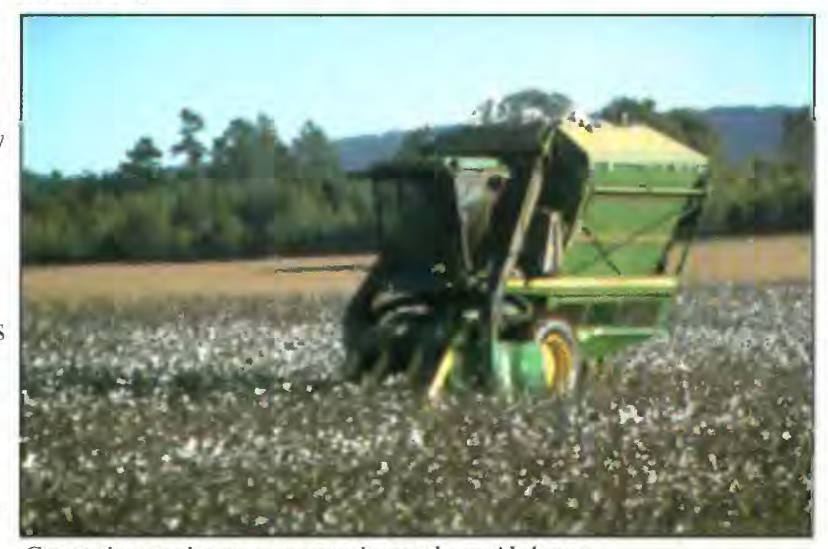

Cotton is a major crop grown in northern Alabama. 




SCHEDULE OF STUdY ACTIVITIES

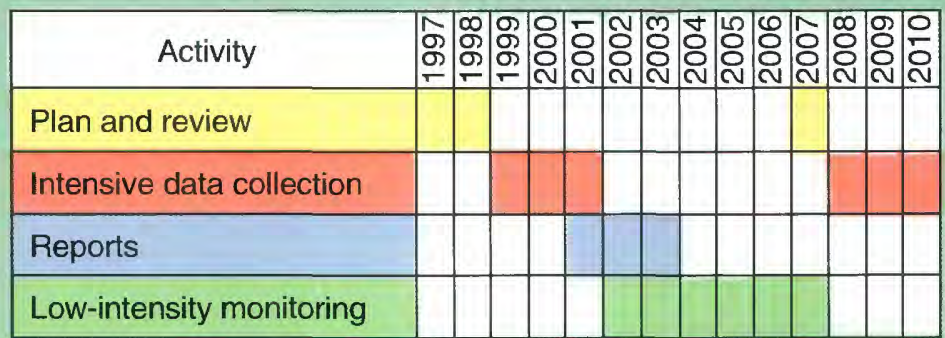

The Lower Tennessee River Basin study is one of 14 NAWQA studies that began in Federal fiscal year 1997 (October 1996). Study planning and design, and analysis of existing data will be done during the first 2 years. After the 2-year planning period, surface- and ground-water and ecological data will be collected intensively for 3 years during a high-intensity phase. A lower intensity phase follows for the next 6 years during which water quality is monitored at a selected number of sites and areas assessed during the high-intensity phase. Alternating high- and low-intensity monitoring phases allows the NAWQA Program to examine trends in water quality over time in a cost-effective manner, eventually assessing about two-thirds of the Nation's water resources.

During the planning period, existing data and results from previous studies will be reviewed to identify gaps in the current data and to help understand the primary physical, chemical, and ecological factors that affect water quality in the study unit. Information obtained from review of previous studies, along with reconnaissance of existing monitoring stations and candidate sampling sites, will be used to design a sampling program for the study unit.

During the high-intensity phase, new chemical, physical, and ecological data will be collected from selected areas at local and regional scales to describe the quality of water throughout the study unit. These data will be used to determine the water chemistry of streams and aquifers; the quantity and quality of suspended sediment and bottom sediments in streams; the variety and number of fish, benthic invertebrates, and algae in streams; and the presence of contaminants in fish tissues. Individual streams, aquifers, and biological species representative of the most important water resources and water-quality concerns in the study unit and the Nation are selected for sampling and analysis. A series of technical and nontechnical reports describing the results of high- and low-intensity-phase data collection and analysis are planned. 


\section{AsSESSING WATER QUALITY IN THE LOWER TENNESSEE RIVER BASIN STUDY UNIT}

The NAWQA Program is designed to assess the status of and trends in the quality of the Nation's ground- and surface-water resources and to link the status and trends with an understanding of the natural and human factors that affect the quality of water. Consistent data collection and assessment methods in all NAWQA studies make this possible and are critical for providing uniform and comparable information on water quality for the Nation. Surface-water, ecological, and ground-water studies are done at local (a few square miles to hundreds of square miles) and regional (thousands of square miles) scales to help understand water-quality conditions and issues in a study unit. NAWQA study-unit data collected using this multiscale, interdisciplinary approach will be aggregated to provide national-scale water-quality assessments. Partnerships and cooperative studies between local, State, and Federal agencies can be developed to help meet specific needs. The basic design described in the following sections is similar among NAWQA study units nationwide.

\section{Surface Water}

Surface-water quality is monitored at two types of sites, basic-fixed sites and intensivefixed sites, according to the frequency of the sampling. Most NAWQA study units have about eight basic-fixed and four intensivefixed sites. Basic-fixed sites are sampled on a regular basis, usually monthly, for 2 years during the 3-year high-intensity phase. Intensive-fixed sites are monitored more frequently for at least 1 year to characterize short-term variations of water quality. Both types of sites are used to monitor water quality constituents, such as basic field properties, major ions, nutrients, and pesticides. Volatile organic compounds (VOC's) and trace elements also may be monitored at selected sites. Monitoring sites are selected to determine representative water quality conditions in relation to important environmental settings in the study unit.

Basic-fixed or intensive-fixed sites are further classified as either indicator or integrator sites. Indicator sites represent relatively homogeneous and usually small basins associated with environmental settings, such as a specific land use that is considered to be important for understanding water quality in the study unit. Integrator sites are established at downstream points in large drainage basins that incorporate complex combinations of land-use settings. Water quality at integrator sites reflects the effects of multiple land uses and transport in the basin.

Synoptic surface-water sampling can be used to address a selected issue in one river basin or to provide greater spatial coverage and allow investigators to assess whether basic-

fixed or intensive-fixed sites are representative of streams throughout the study unit. Synoptic surface-water sampling involves short-term investigations of specific water-quality conditions at numerous sites during selected hydrologic periods, such as periods of low streamflow.

\section{Ecology}

Ecological studies in conjunction with surface-water sampling activities are conducted to provide insight into ecological variability over time, relations between water quality and community structure and stability, and ecological differences with respect to various environmental settings. Aquatic biological communities are surveyed at basic- and intensive-fixed sites during the 3-year high-intensity phase. These investigations are conducted along delineated stream reaches and include aquatic and riparian habitat assessments and annual surveys of fish, algal, and benthic invertebrate communities. Trace elements and synthetic organic compounds are analyzed in bed sediment and fish tissue at selected sites to determine their occurrence and distribution and relation to land use and environmental setting. Ecological synoptic studies are conducted to evaluate spatial variability of biological communities or address issues of special concern within the study unit.

\section{Ground Water}

Ground-water studies in a typical NAWQA study are composed of three components:

(1) study-unit survey, (2) land-use studies, and (3) an optional flow-path study. The study-unit survey is intended to characterize water quality in the major aquifers of the study unit without targeting specific land uses. About 30 wells are randomly selected for sampling in each major aquifer subunit in the study unit. Ground-water samples are analyzed for major ions, nutrients, and pesticides. Trace elements and VOC's also may be monitored.

Land-use studies attempt to characterize the quality of recently recharged ground water associated with a particular land-use setting. Land-use studies emphasize shallow aquifer systems so that the influences of land-use practices and environmental settings can be assessed. About 30 wells are randomly selected within a selected land-use setting for an aquifer. Results from land-use studies will be compared with results from study-unit surveys to determine the effect of land use on ground-water quality.

Flow-path studies are intended to help identify and quantify processes controlling shallow ground-water movement and quality. These studies, performed in selected study units, are designed to trace chemical changes that occur in water as it enters the ground-water flow system, travels along a flow path. and eventually discharges into surface waters.

\section{COMmunication AND COORDINATION}

Communication and coordination between the U.S. Geological Survey and other scientific and land-and water-management organizations are critical components of the NAWQA Program. Each study unit maintains a liaison committee consisting of representatives from Federal, State, and local agencies, universities, the private sector, watershed organizations, and others who have water-resource responsibilities and interests. Activities include the exchange of information about regional and local water-quality issues, identification of sources of data and information, assistance in the design and scope of study products, and the review of study planning documents and reports. The liaison committee for the Lower Tennessee River Basin study met for the first time in November 1997.

The overall success of the Lower Tennessee River Basin NAWQA study will depend on the advice, cooperation, and information from many Federal, State, regional, and local agencies, and the public concerned about water resources in the basin. The assistance and suggestions of all are welcome.

\section{SUGGESTIONS FOR FURTHER READING}

Gilliom, R.J., Alley, W.M., and Gurtz, M.E., 1995. Design of the National Water-Quality Assessment Program: Occurrence and distribution of water-quality conditions: U.S. Geological Survey Circular 1112, 33 p.

Leahy, P.P., Rosenshein, J.S., and Knopman. D.S., 1990, Implementation plan for the National Water-Quality Assessment Program: U.S. Geological Survey Open-File Report 90-174, 10 p.

\section{FOR MORE INFORMATION}

Information on technical reports and hydrologic dat: related to the NAWQA Program can be obtained from:

Michael D. Woodside, Study Chief

Lower Tennessee NAWQA

U.S. Geological Survey

640 Grassmere Park. Suite 100

Nashville, TN 37211

(615) $837-4706$

Internet: http://wwwrvares.er.usgs.gov/nawqa/ nawqa_home.html

By: Michael D. Woodside and Reavis L. Mitchell, III 